THURSDAY, JANUARY 29, r89r.

\section{UNIVERSITY COLLEGE AND ITS APPEAL FOR FUNDS.}

UNFORTUNATELY it is an economic fact, that, under existing conditions, the highest education cannot be self-supporting. The more advanced the teaching, the smaller the class, and as a result the amount of fees received. The pursuit of knowledge in the highest sense, as has often been said, is one of the nineteenth century forms of "a vow of poverty." Research must be endowed ; if not, it must be alimented by other pursuits, that is, by temporary desertion. But with certain branches of knowledge the teacher is not the sole cause of expense. In pure mathematics a blackboard, which is not a costly piece of apparatus, is almost the limit of his reasonable requirements. In classics and literature generally some maps and photographs content all but the most exacting; a few casts and models in addition place him in a state of pedagogic luxury. But in science, as the word is commonly understood, especially in the physical and natural departments, the teacher requires laboratories and museums, apparatus and specimens, which often are costly. Science, in short, as unfriendly critics in other departments are wont to say, is like a daughter of the horse-leech, always crying "give, give."

At the present time the two University Colleges in London are suffering from the pinch of poverty, and fearing that atrophy of the purse will result in diminution of efficacy. University College and King's College are appealing to the public simultaneously and with mutual goodwill, for a capital sum to enable them to provide for several pressing wants, more especially for additional laboratories and appliances required by students in an age of scientific progress. Of these two colleges, the former may be said to appeal urbi et orbi. It was founded some sixty years ago, at a time when the older universities were closed to all who could not subscribe to certain theological tests, practically to all but members of the Established Church of England. This position it has ever maintained. Its chairs and its lecture-rooms are open to all without respect of creed.

A committee is now being formed in order to make an appeal to the public, and especially to the citizens of London, on the basis of a statement issued by the Council of University College. It asks for a sum of not less than fifty thousand pounds, to be devoted mainly to the increase of buildings and appliances for teaching. The most pressing need is a new physical laboratory. That which at present exists was opened in the session of 1867-68. It was not built for the purpose, being merely one of the College lecture-rooms, but it was the first laboratory of its kind opened in London. Since then other rooms have been added, but all the arrangements are of a makeshift character. Additional space is absolutely necessary. At present the students are too much crowded; it is impossible to keep the more important instruments in fixed places, so that much time is lost and risk of injury incurred by moving them about, and advanced work or original investigation has become

NO. I IO9, VOL. 43] almost impossible. Grave difficulties also arise from want of steadiness in the floors, and from unfavourable magnetic conditions caused by local circumstances, such as the arrangements for warming the building. Hardly less pressing is the need for improving the means of teaching electrical engineering, in which instruction has now been given for about five years with yet more inadequate appliances. At the present moment hardly any branch of technical physics is of greater practical importance, and it cannot be better taught than in a college where a sound knowledge of pure and applied mathematics, of physics and of mechanical engineering, can be obtained.

The last-named of these subjects also calls for funds. The engineering laboratory dates from $\mathrm{I} 878$, and for some years was the only one in this country. The system of laboratory instruction, initiated by the late professor, Mr. A. B. W. Kennedy, has been adopted in all the leading engineering schools in Great Britain. This has led to a very remarkable development in the methods of engineering education, so that additional space and additional machines are required to enable University College to retain the position which it has obtained as an engineering school.

A Professorship of Architecture was founded fifty years ago at University College, and was for long the only Professorship of the kind in England. It is very desirable to form a collection of architectural models, and a school of architectural drawing. The College appears to be a place exceptionally suited for a complete school of architecture, because of the existence of the Slade School of Fine Art, as well as an engineering school.

Further, the Society for the Extension of University Teaching in London finds that the lectures on chemistry and physics, given under its auspices, require to be supplemented by evening classes for laboratory instruction. A scheme is being drawn up, the main outlines of which have been already approved by the Council of University College, to provide for this want; but as the existing laboratories are already fully occupied, and the apparatus in use by more advanced students during the day cannot be cleared away to make room for an evening class, additional rooms will be required.

Lastly, many of the professors are insufficiently remunerated. For instance, with the single exception of English, no language-chair has, as yet, been adequately endowed. The Council is anxious to extend the teaching of European languages and to co-operate with the Imperial Institute in the development of its school of modern Oriental studies, in which work King's College also is giving effective aid. But this work cannot be selfsupporting at present, if, indeed, it ever become so ; and how are good teachers to be secured without some assured stipend?

It is, then, to be hoped that the citizens of London will not prove less liberal in the cause of education than those of Manchester, Liverpool, Birmingham, and other great towns. It may be said that in these the University College is the sole place of higher education, but that in London other institutions now exist in which such training may be obtained. Possibly there may be some truth in this remark, but if so, it would be an ungenerous answer to the present appeal. These two Colleges, and University College especially, have borne the burden and 
heat of the day. For many years it met a great and crying want. It cannot be charged with having failed in its duty. It may point in honest pride to the teachers who have occupied its chairs, to the many men of eminence in science, in literature, and in various professions, especially those of Medicine and Law, who have been trained within its walls. It is a standing monument of the munificence of a past generation; it has, indeed, received, within the last few years, more than one liberal bequest, but these are not applicable to the present, most urgent, need; so that, unless further aid be given, its usefulness must be diminished.

\section{WESTERN CHINA.}

Three Years in Western China: a Narrative of Three Journeys in Szechuan, Kweichow, and Yunnan. By Alexander Hosie, M.A., F.R.G.S., H.B.M.'s Consular Service, China. With an Introduction by Mr. Archibald Little. (London: George Philip and Son, I 89o.)

$\mathrm{N}$ the y'ear $\mathrm{I} 876$ certain serious disputes between Great Britain and China were brought to an end by an agreement known, from the place at which it was negotiated and signed, as the Chefoo Convention. One of the provisions of this famous instrument was that the British Government might send officers to reside at Chungking, on the Yangtsze, in Szechuan province, in order to study the conditions of British trade in that region. Beginning with 1877 , a succession of junior officers of the British Consular Service in China have been stationed at Chungking, and from this great commercial mart as a centre have travelled far and wide in parts of China hitherto wholly, or almost wholly, unknown to the West. The late Mr. Colborne Baber was the first of these, and his travels are recorded in the special volume of the Royal Geographical Society, "Travels and Researches in Western China," which the late Colonel Yule described as "that admirable and delightful narrative which the periodical press has allowed to pass almost absolutely unnoticed-taking it, I suppose, for a Bluebook, because it is blue!" The reports of these officers have from time to time been laid before Parliament, and are amongst the most interesting publications ever issued in this way. Not long ago a report from Mr. Bourne, Mr. Hosie's successor, recorded a journey from Chungking across Yunnan to the frontier of Tonquin, along that frontier towards the sea, and then back again across Kweichow province to Chungking; but this, though full of interesting and important information relating to the country, the people, and especially to the trade between Tonquin and Southern China, remains more or less inaccessible in its present shape. Mr. Hosie has followed Mr. Baber's example, and has prepared for popular perusal an account of his journeyings. $\mathrm{He}$ is fortunate in the time and circumstances of the publication, for, by a recent agreement between the British and Chinese Governments, the town of Chungking is to be opened, under certain conditions, to the trade and residence of British merchants. The book contains an introduction by Mr. Archibald Little, whose name has for some years been associated with efforts to navigate the upper waters of the Yangtsze, and to throw Chungking open to foreign trade.

NO. 1109 , VOL. 43]
Mr. Hosie's journeys carried him in various directions, and had various objects in view ; but, naturally, he avoided as far as possible the footsteps of his predecessors. His first journey, which lasted for nearly ten weeks, took him southward from Chungking into the mountainous province of Kweichow, where he came across the aboriginal Miactsze, now almost extinct, to Kwei-yang-fu, the capital, whence he turned westward to Yunnan-fu, the capital of the province of the same name, and so by the mountains of North-Eastern Yunnan home to Chungking. On this journey, besides the Miao-tsze he first saw the whitewax insect, about which he has much to say later on. The second journey lasted nearly six months, and carried the traveller through a more interesting and less-known region. From Chunking he travelled to the north-west across the great plain of Cheng-tu, noted for its extraordinary fertility, the density of its population, and the wealth of its inhabitants. From another point of view, also, it is notable as the only large area of level ground in all Western China; it is a plateau about 7000 feet above the level of the sea, at the foot of the mountains of Tibet, and has an area of about 2400 miles. Richthofen says of it that there are few regions in China, equal areas compared, which can rival it in wealth and prosperity, density of population and productive power, fertility of climate and perfection of natural irrigation; and there is no other where, at the present time, refinement and civilization are so generally diffused among the population. From the city of Cheng-tu, the administrative capital of Szechuan, Mr. Hosie turned to the southwest through the districts inhabited by the Lolos, an aboriginal tribe, discovered practically by the French Expedition under De Lagrée and Garnier, and further investigated by Mr. Baber and Prof. de Lacouperie. Thence he passed into the famous valley of the Chienchang, and to the city of the same name, the Caindu of Marco Polo, which is the centre of the insect white-wax trade, and following the track of the great Venetian arrived at Tali-fu in Yunnan, the Carajan of Marco. The brine industry which the old traveller found flourishing it was here that cakes of salt were used as currency-still exists. From this city, Mr. Hosie, passing through Yunnan-fu and by the valley of the Chi-hsing River, reached Chungking.

Mr. Hosie's third journey was in one sense the most interesting of all, for, although the country traversed was not all new, the object was to study carefully, for the authorities at Kew, the Chinese insect wax industry. He decided for this purpose to visit the centre of the wax culture of the province, to ascend by the way the sacred Mount Omei, from whose summit the glory of Buddha is said to be visible, and then to strike the Yangtsze at its highest navigable point. The mountain, which is about II,Ooo feet high, has been devoted to the worship of Buddha almost since the beginning of our era, and is sufficiently remarkable from a physical point of view. Mr. Hosie devotes a special chapter to the white-wax insect, and the industry associated with it, in which he traces the carcer of the Coccus pe-la of Westwood from its cradle, through its busy and interesting life, to its dishonoured grave. It is only in quite recent years, and mainly through Mr. Hosie's journey, that the mystery surrounding the industry has been 